\title{
Modeling the Stability of SARS-CoV-2 on Personal Protective Equipment (PPE)
}

\author{
Andrew D. Haddow, ${ }^{1 \star}$ Taylor R. Watt, ${ }^{2}$ Holly A. Bloomfield, ${ }^{2}$ David P. Fetterer, ${ }^{3}$ and David E. Harbourt ${ }^{2}$ \\ ${ }^{1}$ General Dynamics Health Solutions in Support of USAMRIID, Fort Detrick, Maryland; ${ }^{2}$ United States Army Medical Research Institute of Infectious \\ Diseases (USAMRIID), Fort Detrick, Maryland; ${ }^{3}$ ICON Global Public Health Solutions, Fort Detrick, Maryland
}

\begin{abstract}
We modeled the stability of SARS-CoV-2 on personal protective equipment (PPE) commonly worn in hospitals when carrying out high-risk airway procedures. Evaluated PPE included the visors and hoods of two brands of commercially available powered air purifying respirators, a disposable face shield, and Tyvek coveralls. Following an exposure to $4.3 \log _{10}$ plaque-forming units (PFUs) of SARS-CoV-2, all materials displayed a reduction in titer of $>4.2 \log _{10}$ by 72 hours postexposure, with detectable titers at 72 hours varying by material $\left(1.1-2.3 \log _{10}\right.$ PFU/mL). Our results highlight the need for proper doffing and disinfection of PPE, or disposal, to reduce the risk of SARS-CoV-2 contact or fomite transmission.
\end{abstract}

Transmission of SARS-CoV-2, the causative agent of COVID-19, occurs primarily through respiratory droplets in close contact settings or by airborne transmission in poorly ventilated enclosed spaces. ${ }^{1}$ Contact transmission, also known as fomite transmission, occurs through contact with contaminated materials or surfaces. Personal protective equipment (PPE) worn by healthcare providers is exposed to SARS-CoV-2 while caring for infectious patients, in turn increasing the chances of fomite transmission of the virus during PPE doffing or reuse without prior disinfection. Certain highrisk airway procedures such as intubation or suctioning have the potential to produce large amounts of phlegm, mucus, and/or saliva, in addition to aerosols. ${ }^{2}$ Thus, PPE worn by healthcare workers when performing these or similar procedures are exposed to higher virus concentrations than those worn during lower-risk medical procedures not involving the patient's airway. ${ }^{3}$ Herein, we carried out a pilot study to model the stability of SARS-CoV-2 on common PPE worn in hospitals to simulate a moderate-dose SARS-CoV-2 transmission event that might occur during a high-risk airway procedure on a COVID-19 patient.

Evaluated materials comprised $6.3 \mathrm{~mm}^{2}$ of selected PPE (Table 1). We also evaluated 50/50 nylon/cotton ripstop fabric treated with insect shield (permethrin 0.5\% [\%W/W]: Tullahoma Industries, LLC, Tullahoma, TN). All materials were surface disinfected by ultraviolet (UV) light for 10 minutes, after which they were contained within covered six-well cell culture plates to mimic PPE storage, and incubated at $22 \pm 2^{\circ} \mathrm{C}$ with a relative humidity of $40-50 \%$ in an operating class II biosafety cabinet throughout the duration of the experiment. Triplicate samples of each material were exposed to $50 \mu \mathrm{L}$ of SARS-CoV-2 (USA-WA1/2020, GenBank accession no. MN985325.1), with the challenge dose being $4.3 \log _{10}$ plaqueforming units (PFUs). This dose was selected based on reported viral RNA loads in sputum of human clinical samples. ${ }^{4}$ Samples were collected at 4, 8, 24, 48, and 72 hours postexposure. A 72-hour time frame was selected as it coincides with a common work schedule observed by many intensive care unit personnel (e.g., nurses) in the United States (three 12-hour shifts worked over three consecutive days of the week) who may need to reuse PPE day after day because of

*Address correspondence to Andrew D. Haddow, General Dynamics Health Solutions in Support of USAMRIID, 1425 Porter St., Fort Detrick, MD 21701. E-mail: andrew.d.haddow.ctr@mail.mil
PPE shortages. Forceps were used to collect samples and place them into $2 \mathrm{~mL}$ tubes containing media as previously described, ${ }^{5}$ after which forceps were disinfected between samples using $5 \%$ MicroChem $^{\mathrm{TM}}$ Plus followed by $70 \%$ ethanol. Samples were then stored at $-80^{\circ} \mathrm{C}$ before quantification of infectious virus. Virus titration was performed in duplicate via plaque assay on Vero 76 cells (ATCC, Manassas, VA; CRL1587) as previously described, ${ }^{5}$ with the limit of detection being $1.0 \log _{10}$ PFU/mL.

Half-lives were estimated by fitting a Poisson regression to each sample, and $t$-statistic Cls were computed on the log half-lives. Predicted mean titers were based on an overdispersed Poisson generalized estimating equation. Analyses were implemented in SAS version 9.4 (SAS Institute Inc., Cary, NC).

We found an inverse relationship between SARS-CoV-2 stability on material surfaces and time (Figure 1), as reported in previous studies. ${ }^{5-15}$ At 72 hours postexposure, all PPE materials had similar detectable titers, with the exception of the $3 \mathrm{M}^{\mathrm{TM}}$ Versaflo ${ }^{\mathrm{TM}}$ economy hood (shroud fabric), Saint Paul, $\mathrm{MN}$, which had a titer of $1.1 \log _{10} \mathrm{PFU} / \mathrm{mL}$. By 72 hours postexposure, all materials displayed a reduction in titer $\geq 4.29$ $\log _{10}$, with final titers of $2.3 \log _{10}$ PFU/mL (3M Versaflo economy hood visor), $1.9 \log _{10}$ PFU/mL (ILC Dover SENTINEL $\mathrm{XL}^{\circledR}$ BioShield full hood visor, ILC Dover, Frederica, DE), 2.2 $\log _{10}$ PFU/mL (FisherBrand ${ }^{\circledR}$ disposable full face shield antifog, ThermoFisher Scientific, Waltham, MA), $2.1 \log _{10}$ PFU/mL (3M Versaflo economy hood shroud fabric), and $2.1 \log _{10}$ PFU/ $\mathrm{mL}$ (DuPont ${ }^{\mathrm{TM}}$ Tyvek $^{\circledR} 400$ Coverall, Midland, MI). The geometric mean half-life of all PPE materials varied from between 6.74 and 10.05 hours (Table 1 and Supplemental Figure 1), with the ILC Dover SENTINEL $X L^{\circledR}$ BioShield full hood visor and shroud fabric displaying the shortest half-life. Viable virus on the Insect Shield treated 50/50 nylon/cotton ripstop fabric decreased rapidly, $2.8 \log _{10} \mathrm{PFU} / \mathrm{mL}$ at 4 hours postexposure, and $2.1 \log _{10}$ PFU/mL at 8 hours postexposure, and by 24 hours postexposure, no viable virus was detected, with the geometric mean half-life being 0.90 hours $(95 \% \mathrm{Cl}$ : 0.645-1.249).

SARS-CoV-2 displayed prolonged stability on those PPE materials evaluated in this study, all of which had infectious SARS-CoV-2 present at least 72 hours postexposure. A recent preprint reported virus recovery at 14 days postexposure on the plastic visor of the 3M Model BE-10L powered airpurifying respirators hood, and at 21 days postexposure on 
TABLE 1

Personnel protective equipment evaluated and associated geometric mean half-life in hours by material

\begin{tabular}{|c|c|c|c|c|}
\hline Product & Manufacturer & Material & Material description & Geometric mean half-life $(95 \% \mathrm{Cl})$ \\
\hline 3M Versaflo economy hood & 3M (Cat No. S-403) & $\begin{array}{l}\text { Visor } \\
\text { Shroud fabric }\end{array}$ & $\begin{array}{l}\text { Polyethylene terephthalate glycol } \\
\text { Polypropylene-coated nonwoven } \\
\text { polypropylene }\end{array}$ & $\begin{array}{l}10.05(9.496-10.642) \\
9.12(8.444-9.858)\end{array}$ \\
\hline $\begin{array}{l}\text { ILC Dover SENTINEL XL } \\
\text { BioShield full hood }\end{array}$ & ILC Dover (Cat No. S-2028) & $\begin{array}{l}\text { Visor } \\
\text { Shroud fabric }\end{array}$ & $\begin{array}{l}\text { Optically clear polyester } \\
\text { Spunbound polypropylene nonwoven } \\
\text { with a polyethylene outer film }\end{array}$ & $\begin{array}{l}8.72(7.615-9.981) \\
6.74(5.639-8.051)\end{array}$ \\
\hline $\begin{array}{l}\text { FisherBrand disposable full } \\
\text { face shield antifog }\end{array}$ & $\begin{array}{r}\text { ThermoFisher Scientific } \\
\text { (Cat No. 19-460-102) }\end{array}$ & Visor & $\begin{array}{l}\text { Polyester treated with an antifog and } \\
\text { antistatic coating }\end{array}$ & $8.83(7.383-10.554)$ \\
\hline DuPont Tyvek 400 coverall & DuPont (Cat No. TY127SWH) & Fabric & DuPont Tyvek 400 & 9.08 (7.635-10.802) \\
\hline
\end{tabular}

DuPont Tyvek 400 using stabilized virus containing mucin, bovine serum albumin, and tryptone, ${ }^{15}$ whereas our study used virus in media. Although we found the predicted half-life of SARS-CoV-2 on PPE ranged from 6.74 to 10.05 hours (depending on the PPE material), it is important to note that between 1.9 and $2.3 \log _{10} \mathrm{PFU} / \mathrm{mL}$ of infectious virus remained on those PPE evaluated in this study at 72 hours postexposure. This is in contrast to SARS-CoV-2 viability on
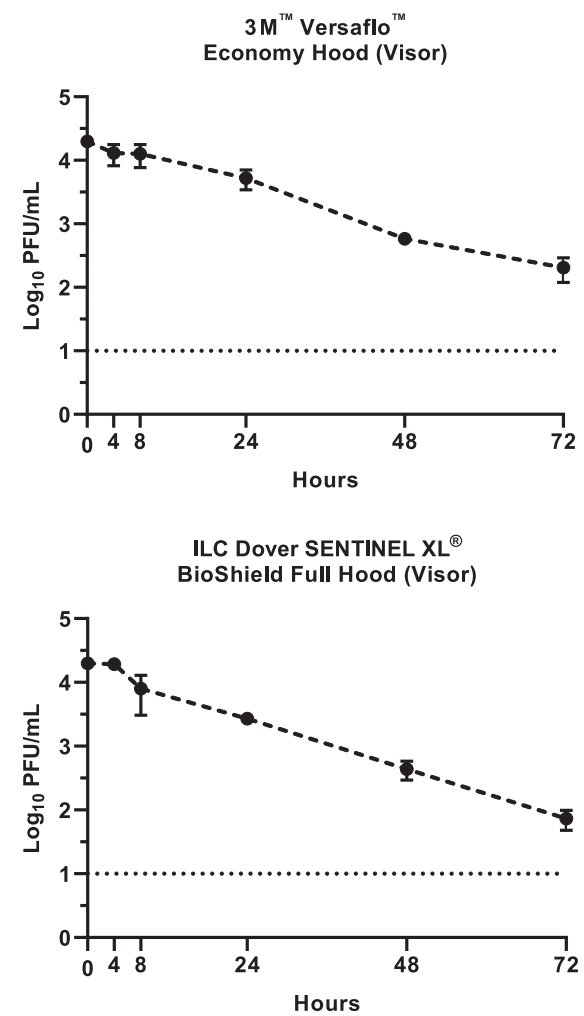

$3 \mathbf{M}^{\mathrm{TM}}$ Versaflo $^{\mathrm{TM}}$
Economy Hood (Shroud Fabric)

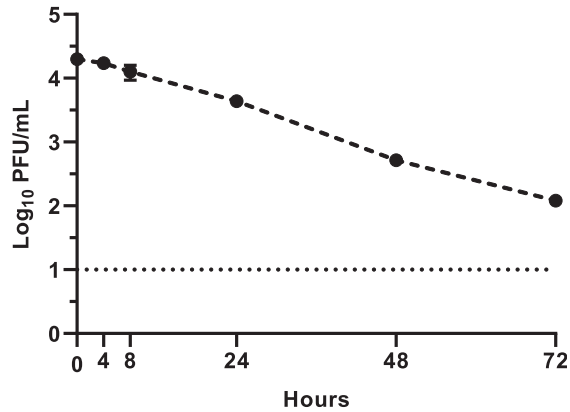

C Dover SENTINEL XL ${ }^{\circledR}$

BioShield Full Hood (Shroud Fabric)

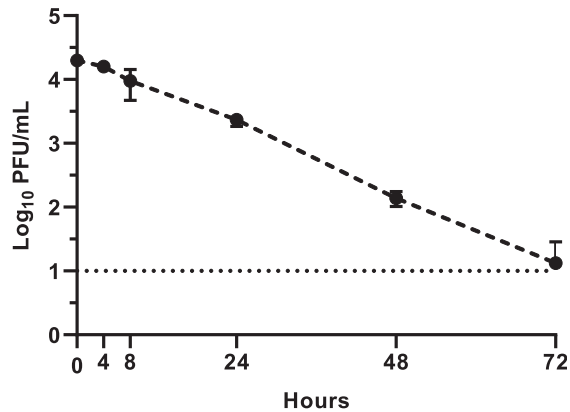

FisherBrand ${ }^{\circledR}$ Disposable Full Face Shield Anti-Fog

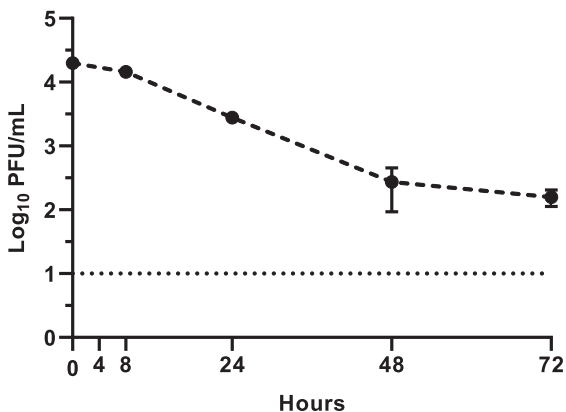

DuPont $^{\text {TM }}$ Tyvek $^{\circledR} 400$ Coverall

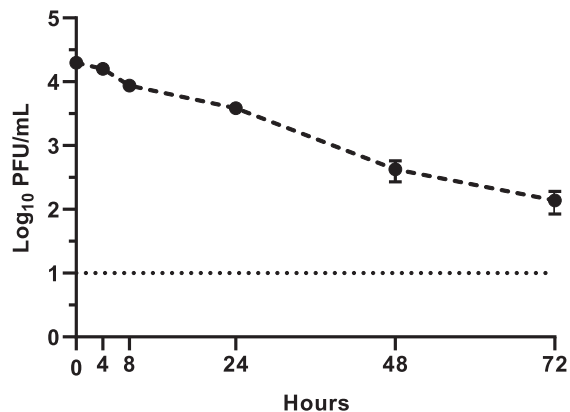

FIGURE 1. Detection of infectious virus on personal protection equipment following a SARS-CoV-2 exposure. No data are reported for the FisherBrand disposable full face shield antifog at 4 hours postexposure as all three samples were inadvertently flipped onto their exposed surface because of a static charge while transferring. The lower limit of detection was $1.0 \log _{10}$ plaque-forming unit (PFU)/mL. 
cloth fabric (i.e., 50/50 nylon/cotton ripstop fabric), which decreased rapidly and was not recoverable at 24 hours postexposure, as reported elsewhere. .,15 $^{5,15}$

The results of this study should be interpreted in light of its limitations. Although the use of six-well tissue culture plates to hold exposed materials allowed air exchange, their use may have reduced virus desiccation. In addition, although exposed materials were not stored in darkness, continuous light was not always present. Similarly, the optical coating on the tissue culture plates and on the biosafety cabinet sash would have limited exposure to UV light reducing virus degradation. We exposed the materials in this study to a moderate dose of SARS-CoV-2 in $50 \mu \mathrm{L}$ of media. Although certain high-risk airway procedures could result in such virus doses/volumes, most healthcare providers PPE would likely receive lower doses of SARS-CoV-2 while caring for COVID-19 patients. Thus, future work is needed to evaluate the stability of SARSCoV-2 on PPE modeling transmission via infectious respiratory droplets $(>5 \mu \mathrm{m})$ and/or droplet nuclei $(\leq 5 \mu \mathrm{m})$ in an effort to model the likelihood of fomite transmission via PPE contaminated in such a manner.

In summary, we demonstrated that SARS-CoV-2 remained infectious on some types of healthcare PPE for at least 72 hours postexposure at $22 \pm 2^{\circ} \mathrm{C}$ following a moderate-dose exposure designed to mimic virus concentrations that might be achieved during high-risk airway procedures. Although our results highlight the stability of SARS-CoV-2 on PPE in an experimental setting, proper doffing and/or disposal or disinfection of PPE would reduce the likelihood of fomite transmission following such procedures.

Received November 24, 2020. Accepted for publication December 11, 2020.

Published online December 22, 2020.

Note: Supplemental figure appears at www.ajtmh.org.

Acknowledgment: The American Society of Tropical Medicine and Hygiene has waived the Open Access fee for this article due to the ongoing COVID-19 pandemic.

Disclaimer: The views expressed in this article are those of the authors and do not reflect the official policy or position of the U.S. Department of Defense or the U.S. Army.

Authors' addresses: Andrew D. Haddow, Taylor R. Watt, Holly A. Bloomfield, David P. Fetterer, and David E. Harbourt, United States Army Medical Research Institute of Infectious Diseases (USAMRIID), Fort Detrick, MD, E-mails: andrew.d.haddow.ctr@mail.mil, taylor.r. watt.mil@mail.mil, holly.a.bloomfield.civ@mail.mil, david.p.fetterer. ctr@mail.mil, and david.e.harbourt.civ@mail.mil.

This is an open-access article distributed under the terms of the Creative Commons Attribution (CC-BY) License, which permits unrestricted use, distribution, and reproduction in any medium, provided the original author and source are credited.

\section{REFERENCES}

1. CDC, 2020. Scientific Brief: SARS-CoV-2 and Potential Airborne Transmission. Available at: https://www.cdc.gov/coronavirus/ 2019-ncov/more/scientific-brief-sars-cov-2.html. Accessed October 13, 2020.

2. Weissman DN, de Perio MA, Radonovich LJ, Jr., 2020. COVID-19 and risks posed to personnel during endotracheal intubation. JAMA 323: 2027-2028.

3. Feldman O, Meir M, Shavit D, Idelman R, Shavit I, 2020. Exposure to a surrogate measure of contamination from simulated patients by emergency department personnel wearing personal protective equipment. JAMA 323: 2091-2093.

4. Pan Y, Zhang D, Yang P, Poon LLM, Wang Q, 2020. Viral load of SARS-CoV-2 in clinical samples. Lancet Infect Dis 20:411-412.

5. Harbourt D, Haddow A, Piper A, Bloomfield H, Kearney BJ, Fetterer D, Gibson K, Minogue T, 2020. Modeling the stability of severe acute respiratory syndrome coronavirus 2 (SARS-CoV2) on skin, currency, and clothing. PLoS Negl Trop Dis 14: e0008831.

6. van Doremalen $\mathrm{N}$ et al., 2020. Aerosol and surface stability of SARS-CoV-2 as compared with SARS-CoV-1. N Engl J Med 382: 1564-1567.

7. Chin AWH, Chu JTS, Perera MRA, Hui KPY, Yen HL, Chan MCW, Peiris M, Poon LLM, 2020. Stability of SARS-CoV-2 in different environmental conditions. Lancet Microbe 1: e10.

8. Biryukov J et al., 2020. Increasing temperature and relative humidity accelerates inactivation of SARS-CoV-2 on surfaces. mSphere 5: e00441-20.

9. Pastorino B, Touret F, Gilles M, de Lamballerie X, Charrel RN, 2020. Prolonged infectivity of SARS-CoV-2 in fomites. Emerg Infect Dis 26: 2256-2257.

10. Smither SJ, Eastaugh LS, Findlay JS, Lever MS, 2020. Experimental aerosol survival of SARS-CoV-2 in artificial saliva and tissue culture media at medium and high humidity. Emerg Microbes Infect 9: 1415-1417.

11. Haddow AD, Watt TR, Bloomfield HA, Shamblin JD, Dyer DN, Harbourt DE, 2020. Stability of SARS-CoV-2 on produce following a low-dose aerosol exposure. Am J Trop Med Hyg 103: 2024-2025.

12. Riddell S, Goldie S, Hill A, Eagles D, Drew TW, 2020. The effect of temperature on persistence of SARS-CoV-2 on common surfaces. Virol J 17: 145.

13. Matson MJ, Yinda CK, Seifert SN, Bushmaker T, Fischer RJ, van Doremalen N, Lloyd-Smith JO, Munster VJ, 2020. Effect of environmental conditions on SARS-CoV-2 stability in human nasal mucus and sputum. Emerg Infect Dis 26: 2276-2278.

14. Fischer RJ et al., 2020. Effectiveness of N95 respirator decontamination and reuse against SARS-CoV-2 virus. Emerg Infect Dis 26: 2253-2255.

15. Kasloff SB, Strong JE, Funk D, Cutts TA, 2020. Stability of SARSCoV-2 on critical personal protective equipment. medRxiv. Available at: https://doi.org/10.1101/2020.06.11.20128884. 